\title{
Activation of rape (Brassica napus L.) embryo during seed germination. V. The first zones of ultrastructural changes and their expansion
}

\author{
MIECZYSLAW KURAŚ \\ Laboratory of Electron Microscopy, Institute of Botany, Warsaw University, \\ Krakowskie Przedmieście 26/28, 00-927 Warszawa, Poland \\ (Received: August 5, 1986. Accepted: October 13, 1986)
}

\begin{abstract}
In the germinating rape embryo the columella and basal part of hypocotyl undergo earliest activation. Its first ultrastructural symptom is the appearance of numerous ER vesicles after $3-6 \mathrm{~h}$ of seed swelling. Their number is the highest in the external layers of the columella and decreases in basipetal direction. Dermatogen cells in the basal zone of the hypocotyl contain the greatest amount of ER structures, whereas decreasing amounts are found in both directions along the embryo axis and centripetally. Further changes in the ER spread in a similar order. The vesicles merge and form a tubular and plate-like ER. Then, they disappear and are replaced by tubular and vesicular forms. The changes in the ER are gradually followed by ultrastructural symptoms of activation of mitochondria, plastids and dictyosomes. The highest number of ER structures and other organelles accumulate in root cells shortly before piercing of the seed coat. After germination their amount decreases and remains almost stable.
\end{abstract}

Key words: rape, root cells, germination, ultrastructural changes

\section{INTRODUCTION}

Synthesis of starch, DNA, mitosis and growth start in two zones of the germinating rape embryo: the columella of the root-cap and the hypocotyl-root boundary, hence they spread wave-like throughout the whole embryo (Kuraś 1986). The question arose how such a course of activation is reflected in the ultrastructure. The ultrastructure of columella and the -hypocotyl-root boundary of the resting embryo differ greatly from that of the remaining cells which are completely filled with storage materials (Kuraś 1984). 


\section{MATERIAL AND METHODS}

Seeds of winter rape (Brassica napus L. var-oleifera, cv. Górczański) ripened as described previously (Kuraś 1984, 1986), were placed on wet filter paper in a moist chamber in darkness. Apical parts of roots and fragments from the hypocotyl-root boundary were taken 3, 6, 14, 18 and $24 \mathrm{~h}$ after seed soaking. The material was fixed and embedded according to the procedure described previously (Kuraś 1984). Ultrathin sections differentiated in uranyl acetate and lead citrate (Reynolds 1963) were examined in a TEM-BS-500 Tesla electron microscope.

\section{RESULTS}

ULTRASTRUCTURE OF THE EMBRYO OF THE SWELLING SEED

After $3 \mathrm{~h}$ of seed swelling the ultrastructure of the embryo alters in the columella, and after $6 \mathrm{~h}$ in the dermatogen at the hypocotyl-root boundary (Figs. 1-5). The electron-density of the cytoplasm decreases and the lipid vesicle and organelle agglomerations become looser. In most cells, however, the lipid bodies are present at the walls similarly as in the dry embryo. The cell nucleus becomes rounded and electron-clearer. The rarefied nucleolus contains clearer areas (Fig. 2). The plastids become rounded they have single short thylakoids and agglomerations of plastoglobules (Fig. 4), but some contain cavities filled with cytoplasm. There are sporadical single small starch grains, especially in the second cell layer. Numerous mitochondria are seen, usually spherical, although in the first columella layer there are some elongated ones, with constrictions. The mitochondrial cristae are numerous and frequently long (Figs. 4 and 5).

Metabolic activation during the first three hours of seed swelling is indicated mostly by changes in the ER. In most radicles these changes appear gradually in the successive columella layers. In two external layers there are short ER tubules, sometimes with numerous swellings and branchings (Fig. 5). The tubules are dispersed throughout the cell or form large agglomerations at the wall. In the deeper columella layers there are numerous ER vesicles of various diameter (Figs. 2 and 4) and their number decreases basipetally. In the promeristem they are scarce, but there are single long ER cisternae, parallel to the nucleus or the cell wall. Sporadically, parallel arrangements of ER cisternae occur. They undergo fragmentation to numerous vesicles and tubules (Fig. 1). In the apical columella layer where starch synthesis begins, there is a characteristic agglomeration of long ER tubules in the close vicinity of plastids (Fig. 3). In the columella and promeristem the nucleolar envelope is smooth and not connected with ER. 
At the hypocotyl-root boundary the ultrastructural changes (Figs. 6-10) are distinctly retarded as compared with those in the columella. Although there appear elongated mitochondria with a larger number of cristae (Fig. 7), the plastids contain as yet no starch (Fig. 8), and the vesicular ER is less abundant (Figs. 6 and 10).

After $6 \mathrm{~h}$ the ER in the columella is much more abundant and still in differentiated forms (Figs. 11-13). Only in the first columella layer the vesicles are less numerous and short ER tubules are dispersed in the cytoplasm (Fig. 13). In all other layers ER undergoes considerable morphological changes. In layers II and IV it is particularly abundant. The vesicles, arranged in parallel strands, coalesce, forming perforated cisternae and plates (Figs. 11 and 12). ER much less profuse in further columella layers, remains in the form of short cisternae or vesicles. In the promeristem there is a small number of long ER cisternae lying close to the nucleus and in the parietal zone (Fig. 11). There are as yet no connections between the ER and the nuclear envelope.

The state of other organelles also indicates the increase in metabolic activity in the columella. There are more plastids and mitochondria, especially in layers II and III (Figs. 11 and 12). The plastids are large, rounded, sometimes constricted, with small depressions and first starch grains. There still is no starch in the promeristem, where plastids contain some plastoglobules (Fig. 11). The mitochondrial cristae are much more numerous and longer than after short soaking, particularly in layers I-III (Figs. 12 and 13). There also are few dictyosomes in the cells of these layers (Fig. 12). In parallel with these changes the number and size of lipid vesicles are also diminished. They are usually dispersed in cells of the lower layers, whereas in the promeristem they form a layer at close to the walls. The protein bodies are unchanged (Fig. 13).

Activation advances more slowly in cells of the hypocotyl-root boundary than in the columella. The amount of ER increases, but only in the first root-cap layer (Fig. 14). In deeper layers cisternae remain around plastids and protein bodies (Fig. 15). These cisternae frequently undergo fragmentation into numerous vesicles (Figs. 15 and 16). Their number decreases in cells in all directions from the hypocotyl-root boundary (cf. e.g. Figs. 15 and 16). Dermatogen cells at this boundary contain few plastids, sometimes constricted, with the first starch grains (Fig. 15).

After $14 \mathrm{~h}$ of seed swelling the ultrastructure indicates that the layers IV and $\mathrm{V}$ of the columella and the promeristem are activated (Figs. 17-20). -In these areas a mass of ER cisternae and stacks of perforated ER plates develop (Fig. 17). At this time perforated plates are not present in layers I and III where they were previously numerous. In these layers in most roots ER disappears almost completely (Fig. 18), but in some roots numerous short tubules and vesicles agglomerate again (Fig. 20). In the promeristematic 
PLATE I

Figs. 1-5. Columella after $3 \mathrm{~h}$ of soaking. Fig. 1 - Promeristem. Poorly developed mitochondria (M) and plastids (PI). Single long endoplasmic reticulum (ER) cisternae and sporadical arrangement of parallel cisternae. $\times 20000$. Fig. 2 - Layer II. ER vesicles and loosened structure of nucleolus $(\mathrm{Nu}) \times 12000$. Fig. 3 - Plastids typical for this stage: lack of starch, plastoglobules $(\mathrm{Pg})$ agglomerations and single lamellae. $\times 18000$. Fig. $4-$ In layer II (lower) abundant ER. mainly tubular, in layer III (upper) mainly vesicular. $\times 20000$. Fig. $5-$ Layer I. Largest amount of tubular ER, mitochondria with cristae and plastids surrounded by ER. $\times 20000$. Cw - cell wall, $\mathrm{Lb}-$ lipid body, $\mathrm{N}-$ nucleus, $\mathrm{Pb}-$ protein body

PLATE II

Figs. 6-10. Hypocotyl-root zone after $3 \mathrm{~h}$ of soaking. Fig. 6-Layer I of root cap (on right), developed ER. Dermatogen (on left). $\times 20000$. Fig. 7. Elongated mitochondria with numerous cristae. Scarce ER. $\times 16000$. Fig. 8 - Dermatogen. Plastids with long thylakoids and plastoglobules. $\times 20000$. Fig. $9-$ Dermatogen. First ER vesicles arising by fragmentation of cisternae surounding protein bodies. $\times 20000$. Fig. $10-$ Layer II of periblem. ER cisternae close protein bodies. $\times 20000$. Abbreviations as on Plate I

PLATE III

Figs. 11-13. Columella after $6 \mathrm{~h}$ of soaking. Ultrastructure development progressing in basipetal direction. Fig. 11 - Promeristem. Ultrastructure least developed: mitochondria, starchless plastids, ER cisternae at cell wall. $\times 18000$. Fig. $12-$ Layer II. ER (cisternae and perforated plates), active mitochondria, plastids with starch $(\mathrm{s}) . \times 18000$. Fig. 13 - Layer I of root-cap. Somewhat less ER than in layer II, protein and lipid bodies. $\times 18000$. D - dictyosome. Other abbreviations as on Plate I

PLATE IV

Figs. 14-16. Hypocotyl-root boundary after $6 \mathrm{~h}$ of soaking. Fig. 14-Layer I of root-cap. Tubular ER, mitochondria and intact protein bodies. $\times 20000$. Fig. $15-$ Dermatogen. ER cisternae around protein bodies and plastids (arrows). $\times 20000$. Fig. $16-$ Subdermatogen.

Forming ER vesicles. $\times 20000$. Abbreviations as on Plate I

PLATE V

Figs. 17-20. Columella after $14 \mathrm{~h}$ of soaking. Fig. $17-$ ER plates in layer V. $\times 20000$. Fig. 18-Lack of ER in central part of columella (layer III) where it had been abundant after $6 \mathrm{~h} . \times 16000$. Fig. $19-$ Layer II. ER related to nuclear envelope (arrows) $\times 16000$. Fig. $20-$ Layer I. Protein bodies undergoing hydrolysis. $\times 16000$. Abbreviations as on Plate I

PLATE VI

Figs. 21-23. Hypocotyl-root boundary after $14 \mathrm{~h}$ of soaking. Fig. 21 - Root-cap cell (on left) and dermatogen cell (on right). Lack of ER. More dictyosomes, mitochondria and plastids better developed than in previous stage. $\times 16000$. Fig. $22-$ Subdermatogen. ER cisternae. Plastids with starch, developed mitochondria. $\times 16000$. Fig. $23-$ Periblem layer II. Abound ER. $\times 16000$. Abbreviations as on Plate I 


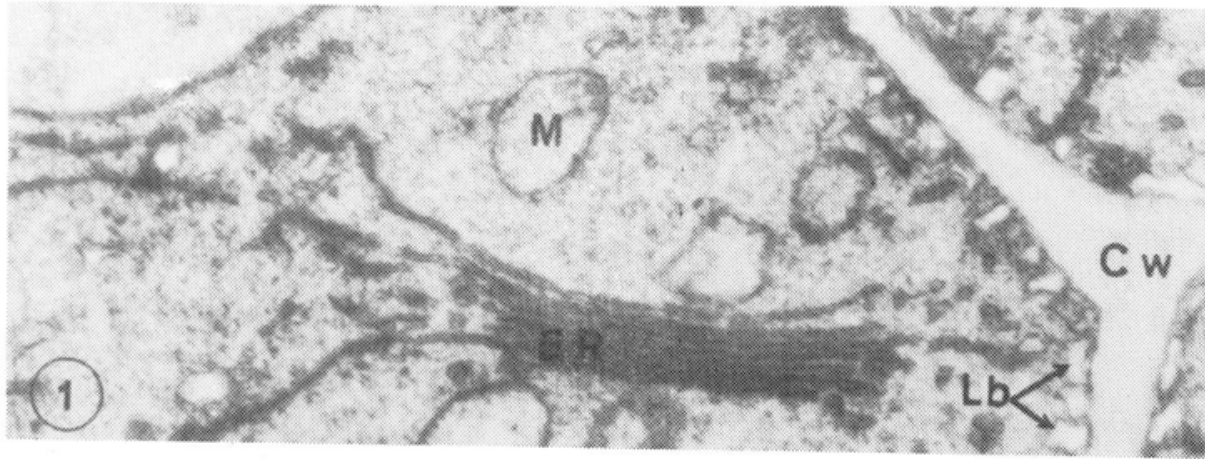

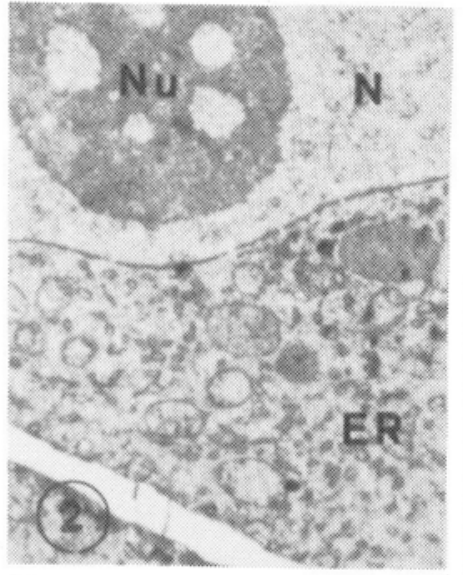

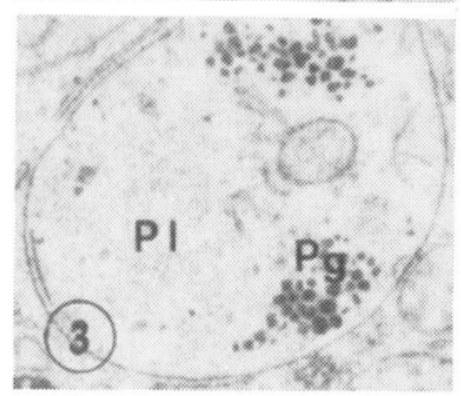

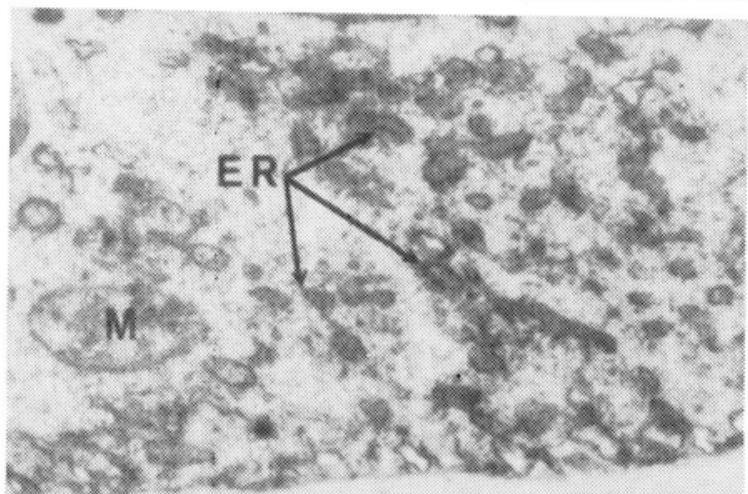

$\mathrm{Cw}$

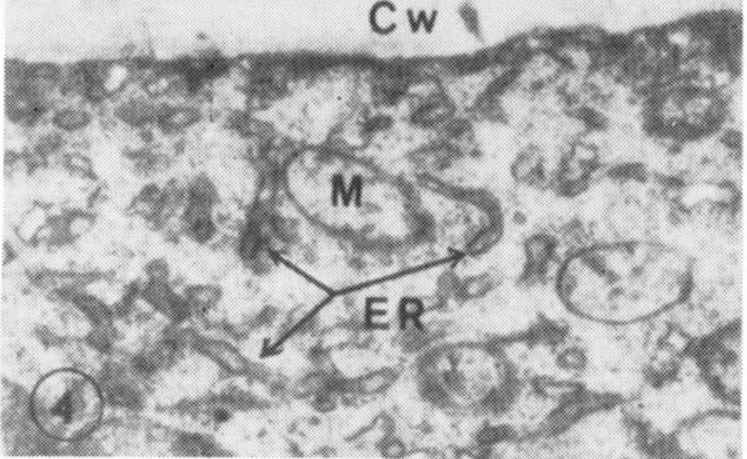

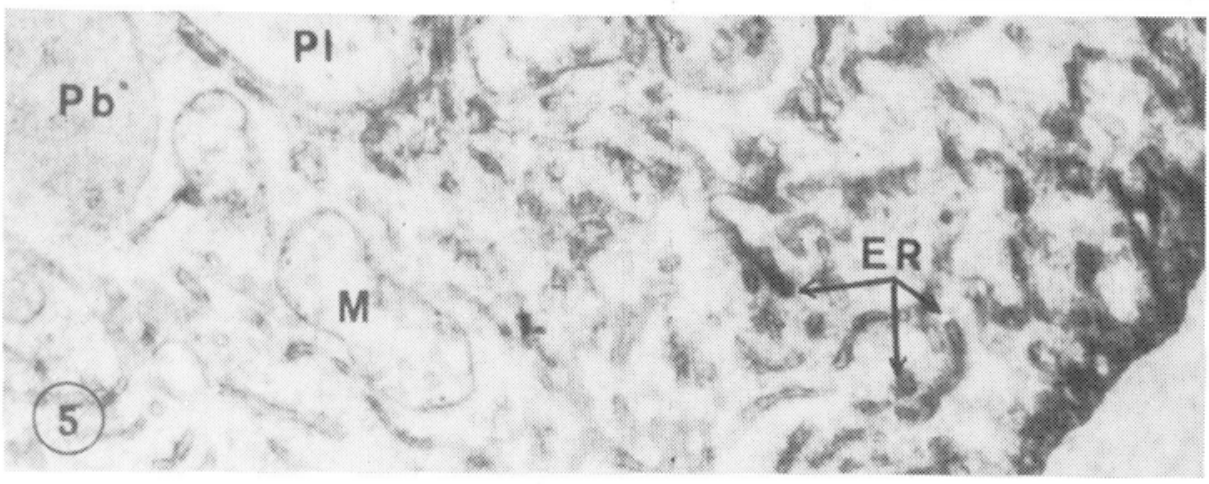



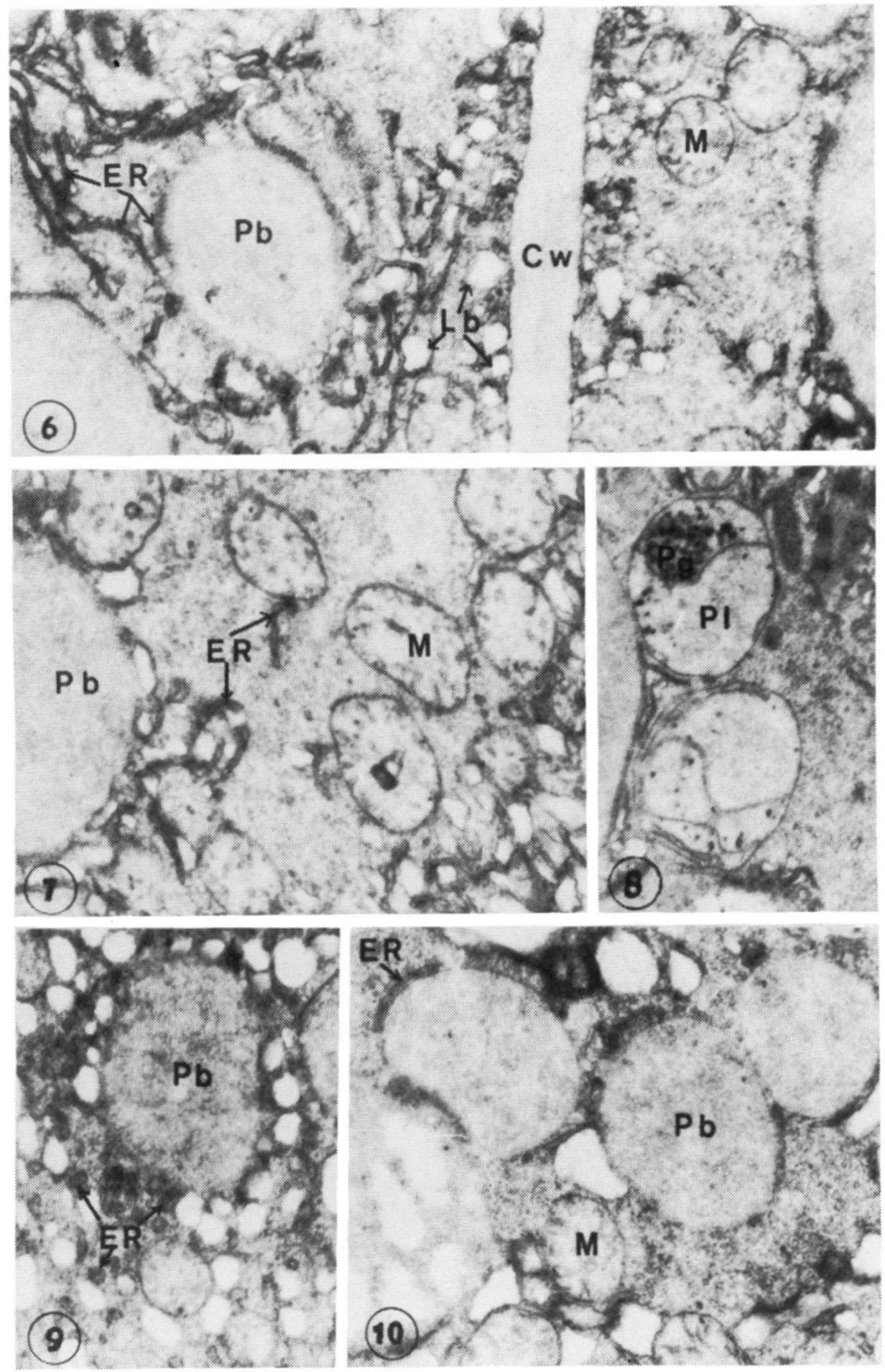


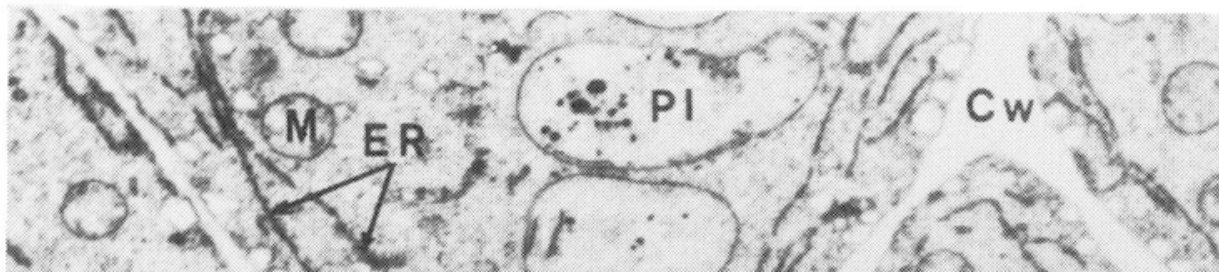

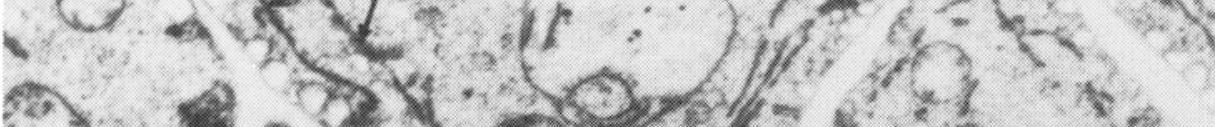

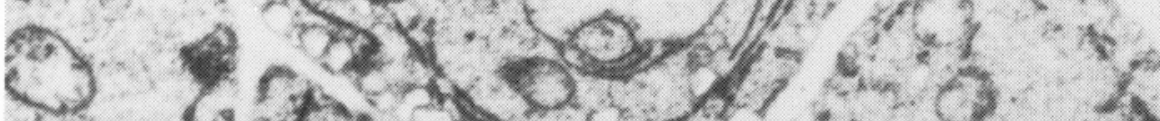

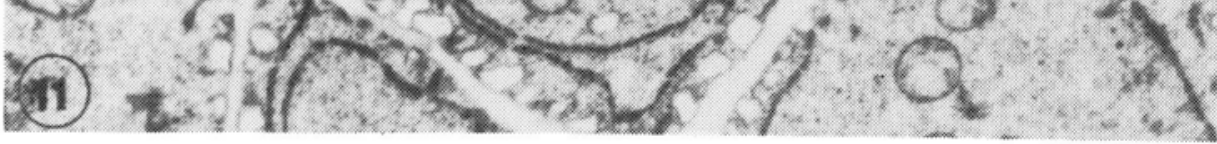

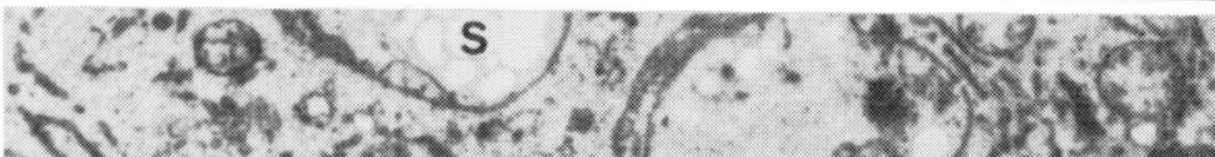
) -1.00

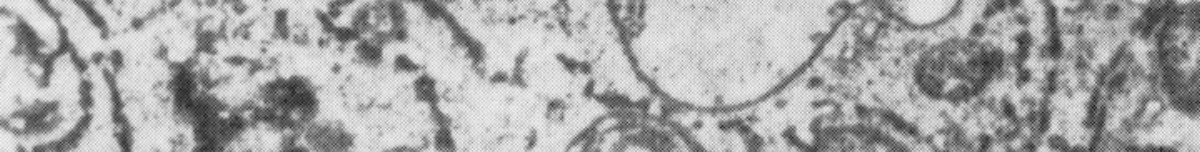
19070025

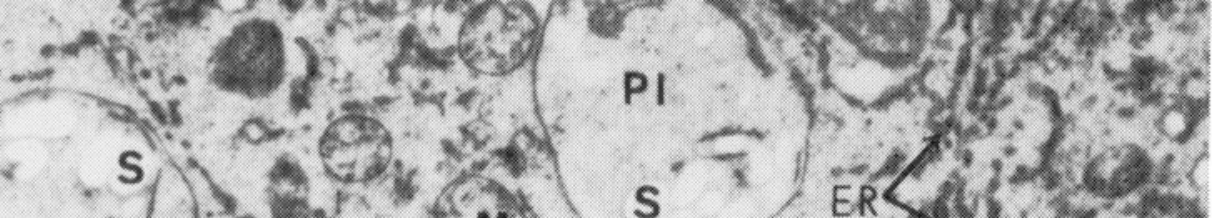

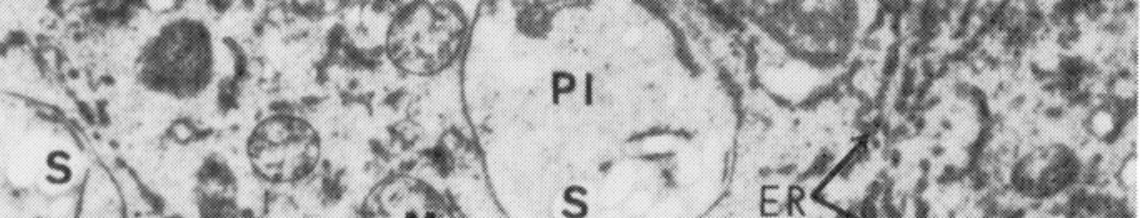
(5) $N$ M S ERSW 35 $35 \mathrm{x}$ -

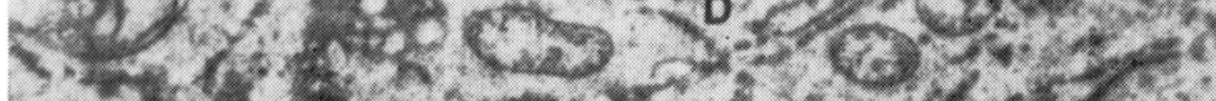
340

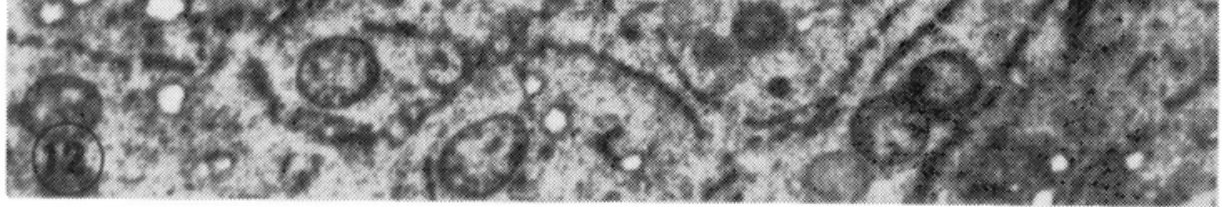

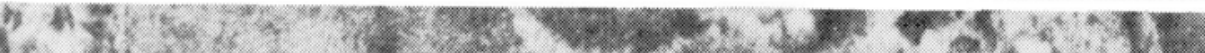

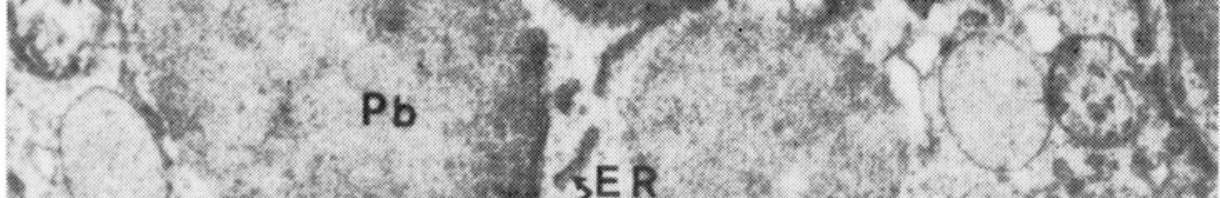

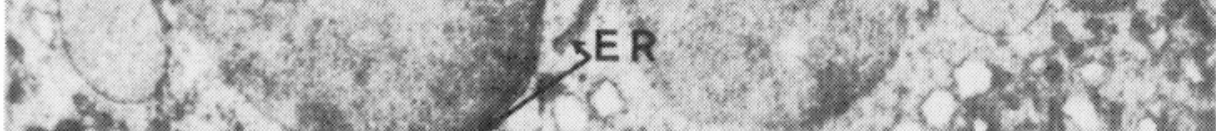

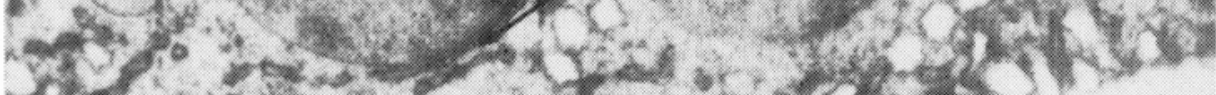

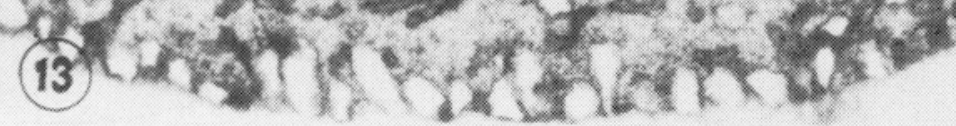



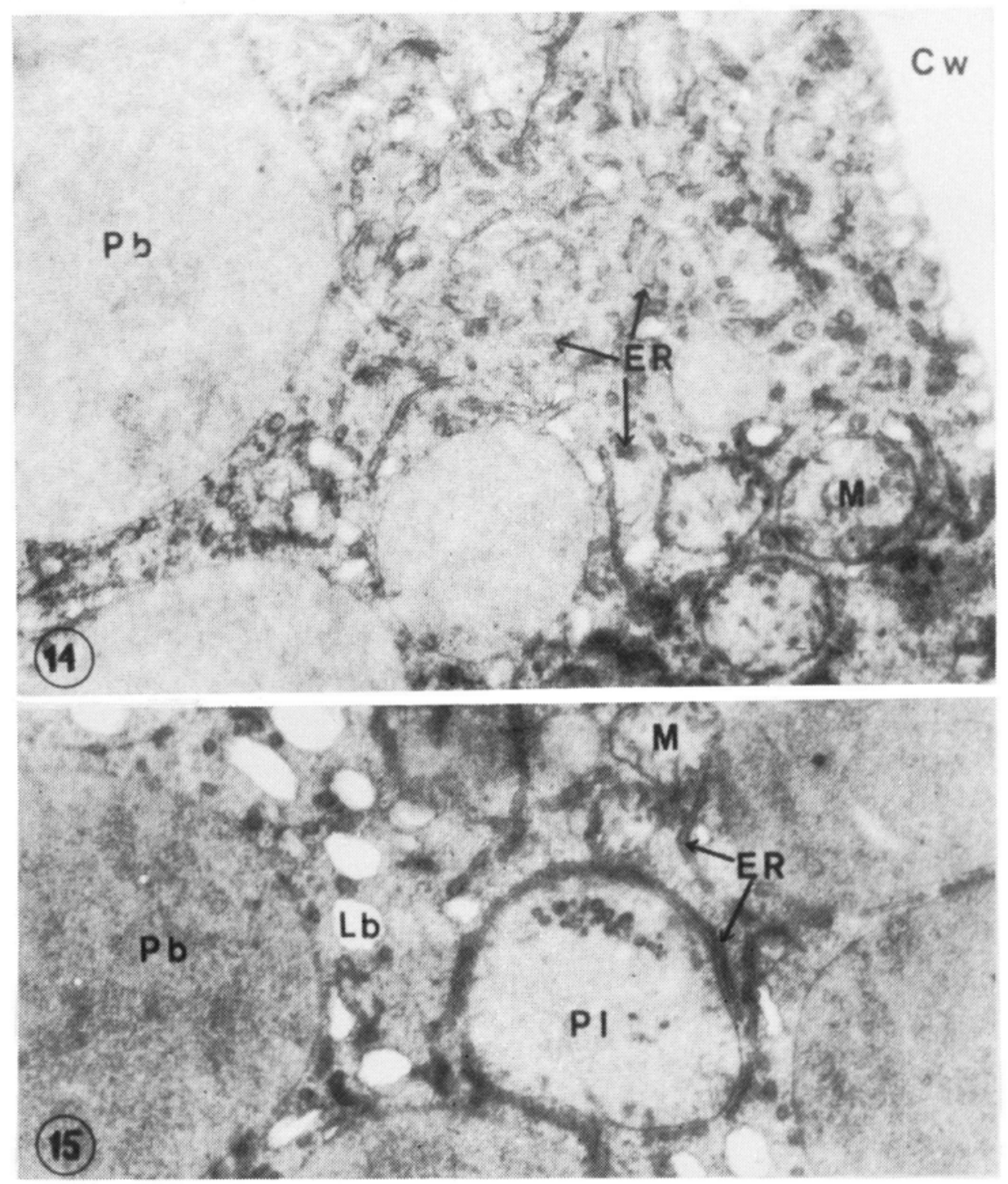

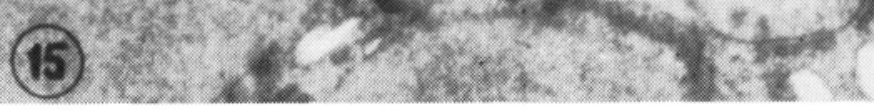

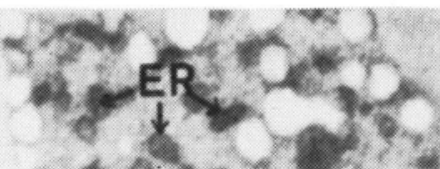

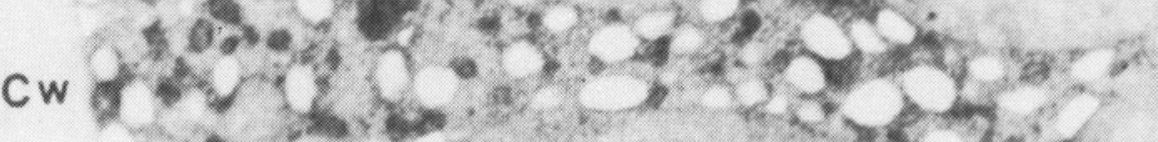

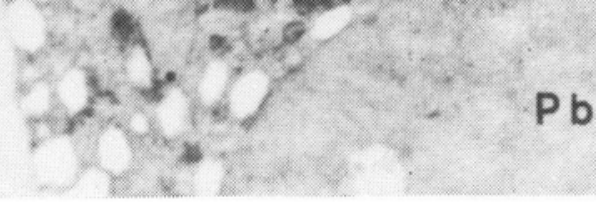

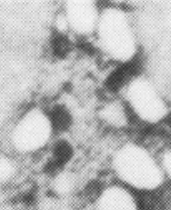




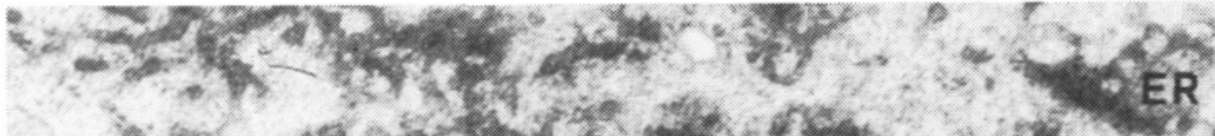

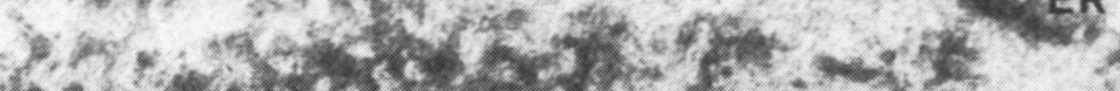

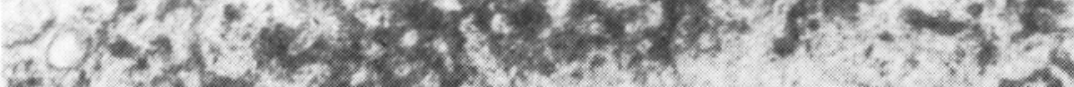
Hath

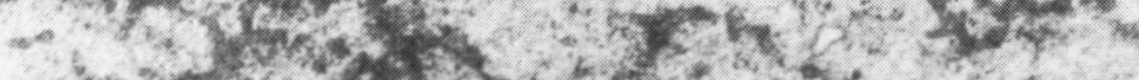

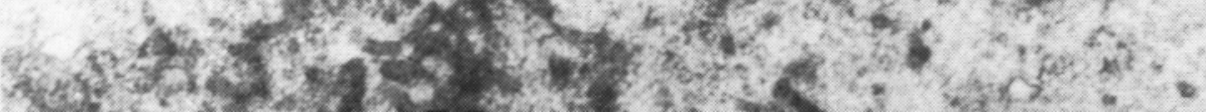

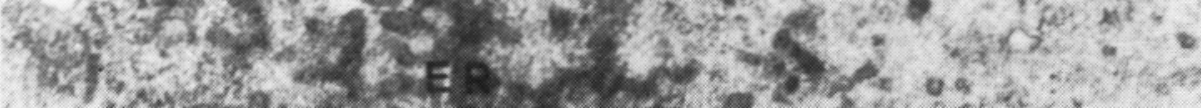

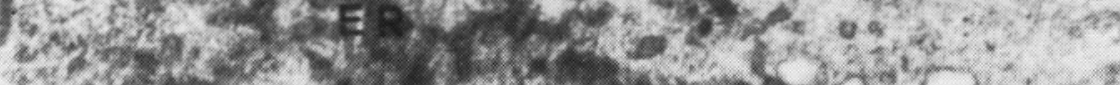

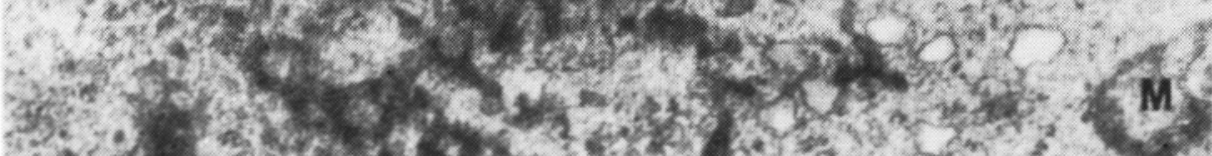

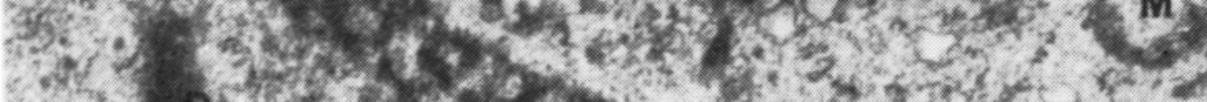

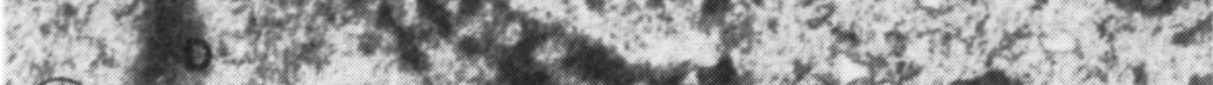

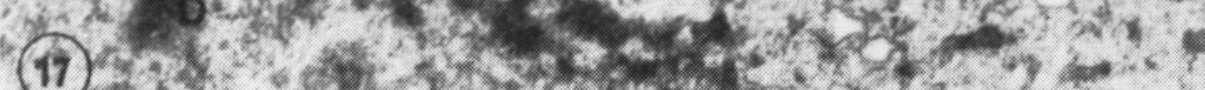

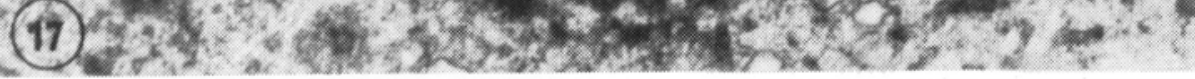

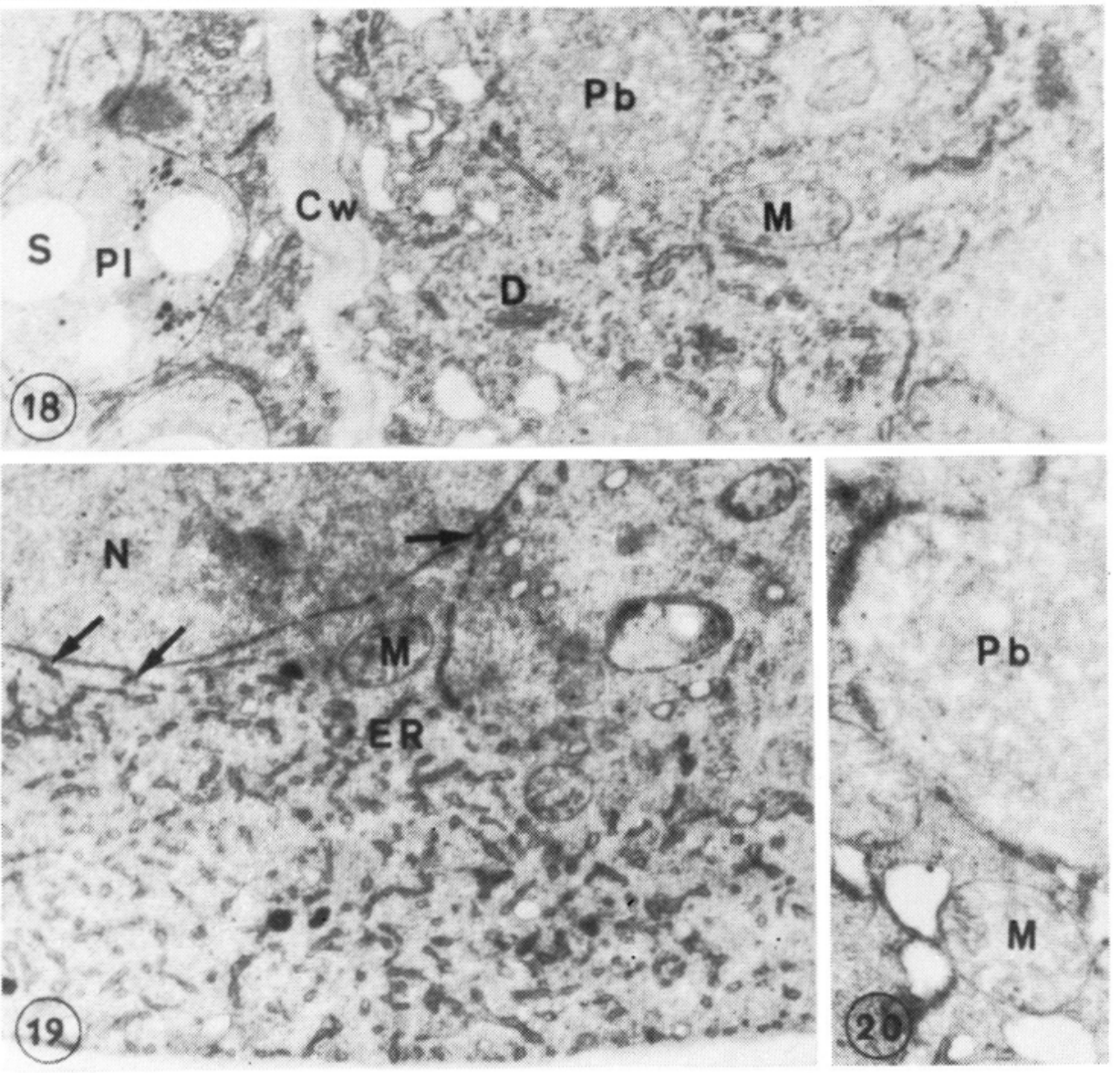




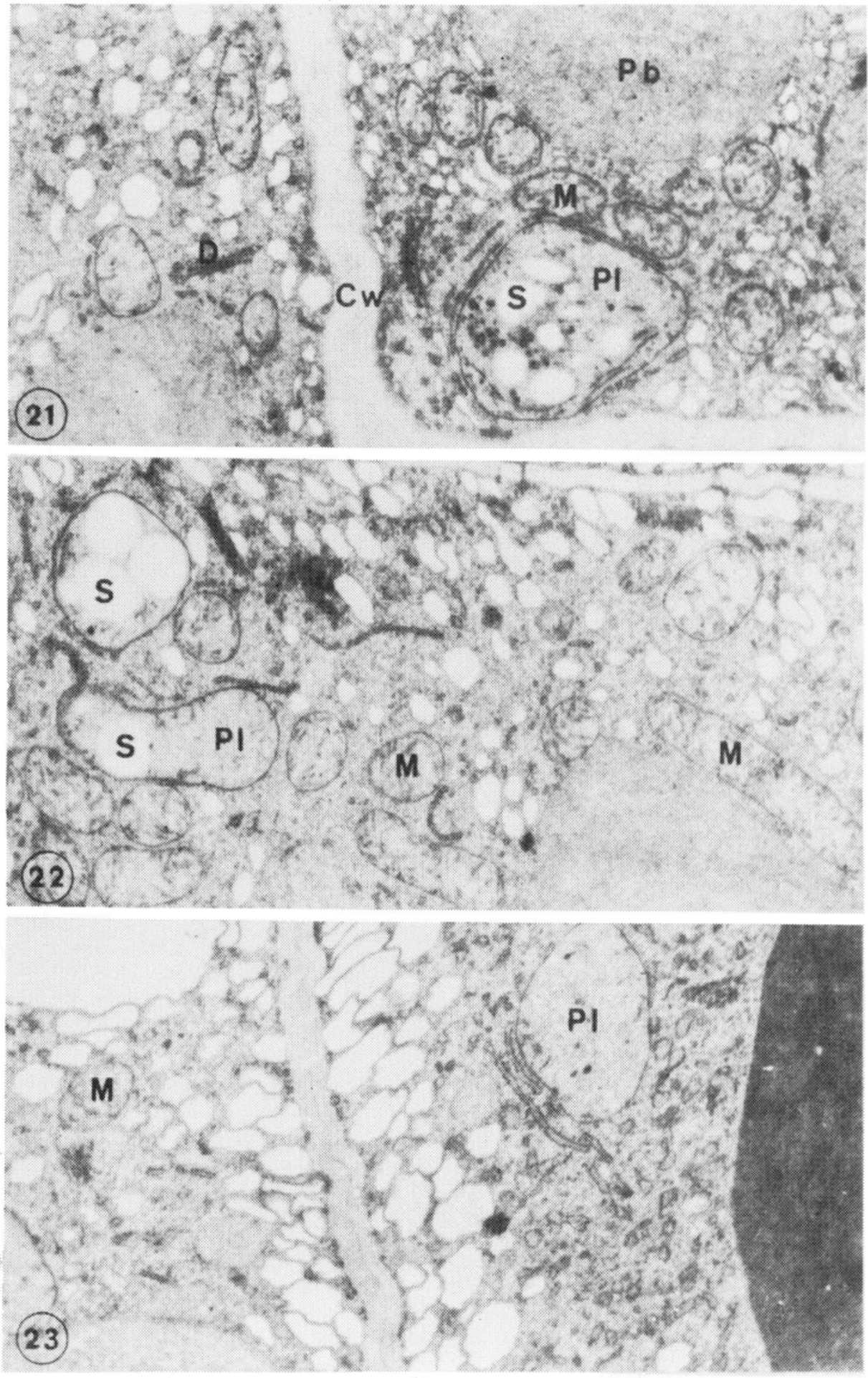




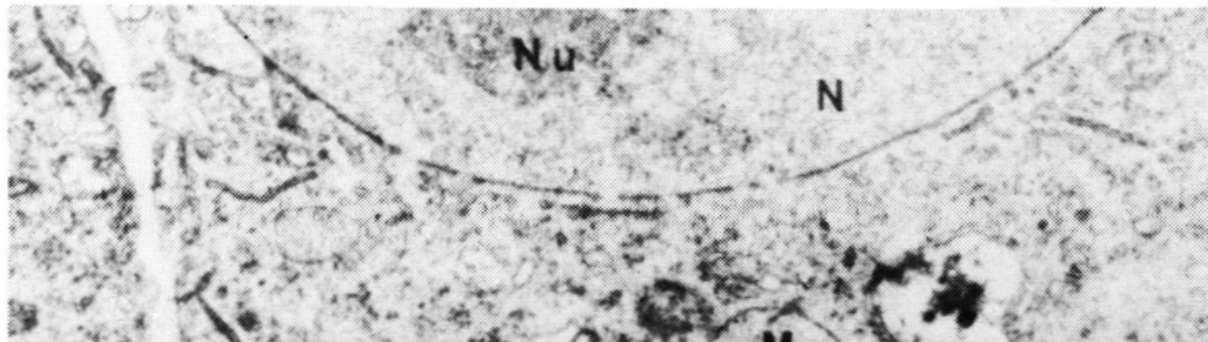

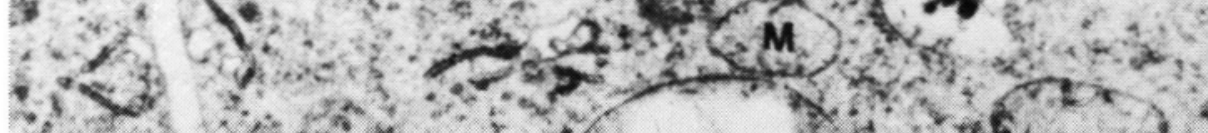

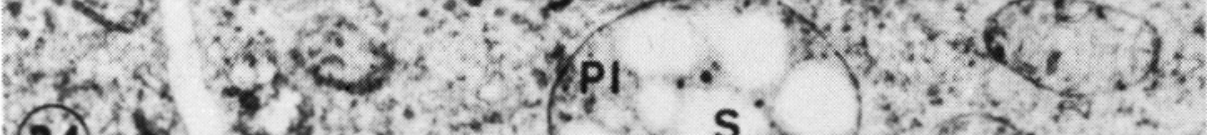
24) 20 .

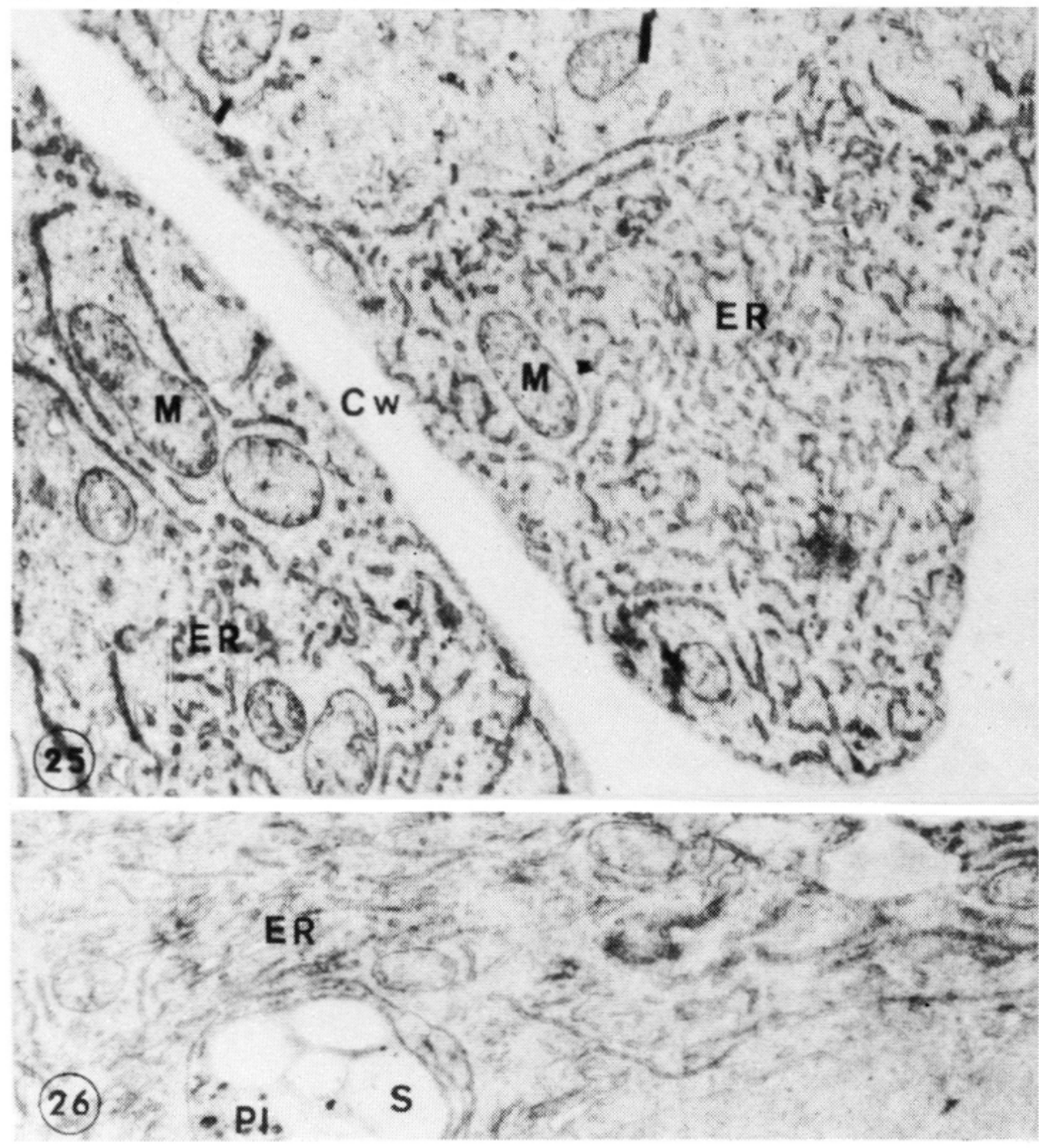



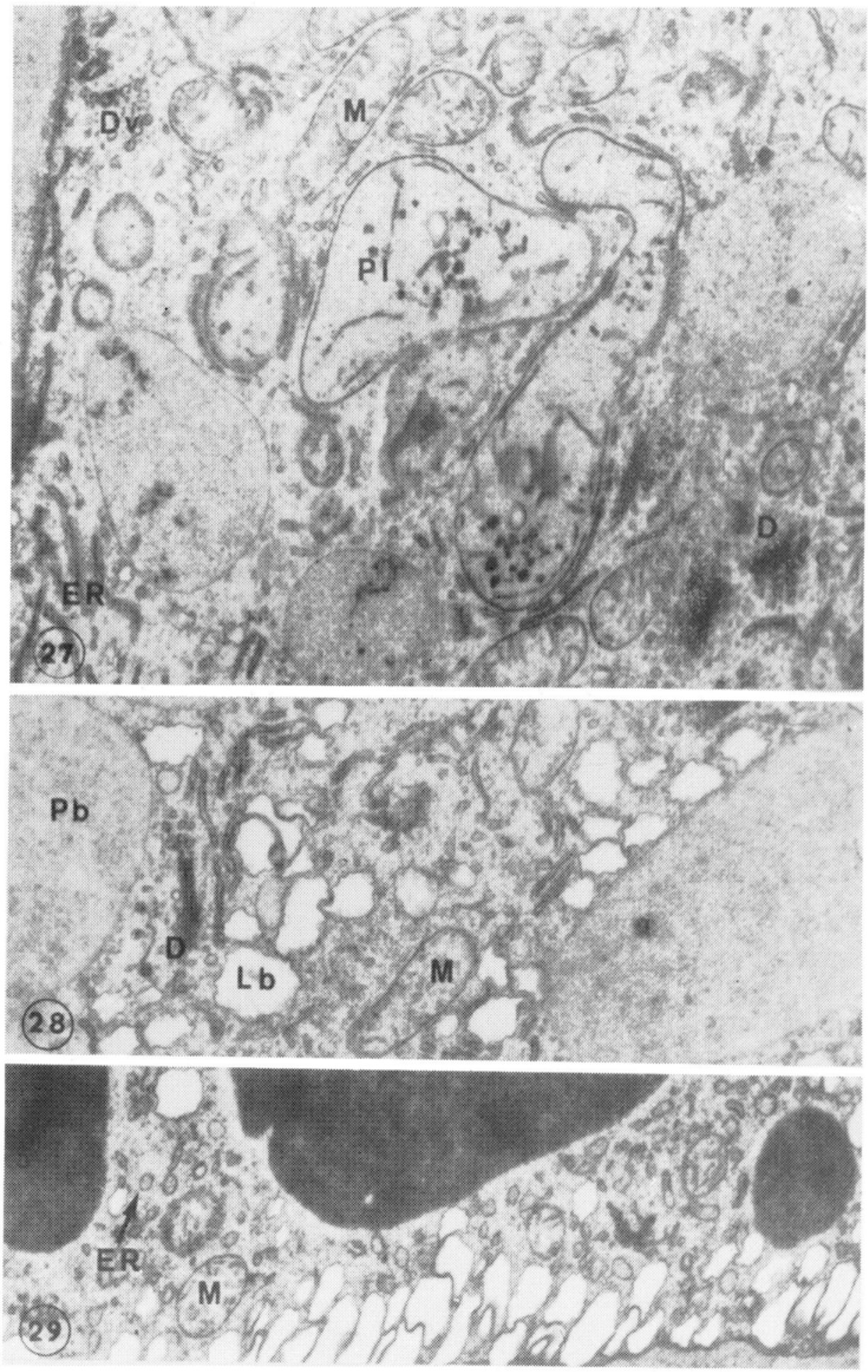
$203 x^{2}+33^{2}$

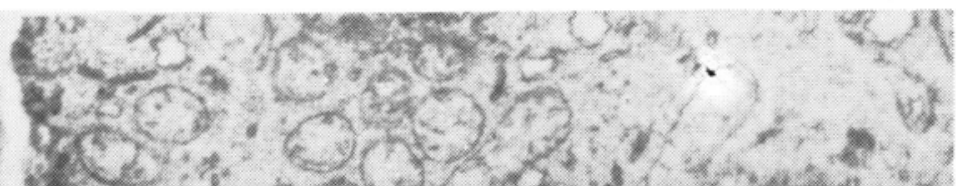

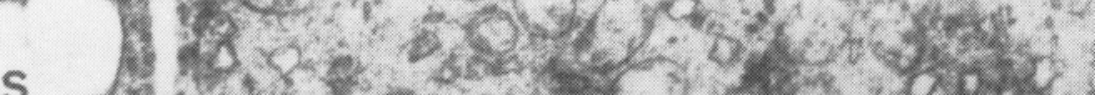

S 18 2.2.

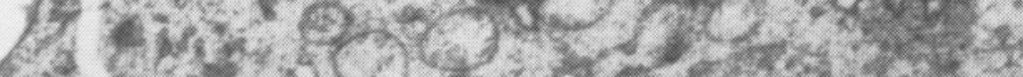
int.

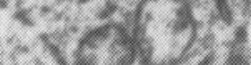
(i. (30) 35,20

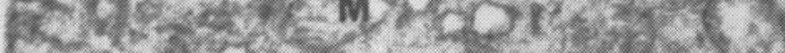

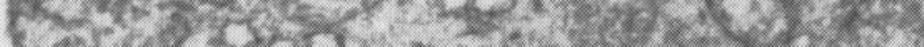

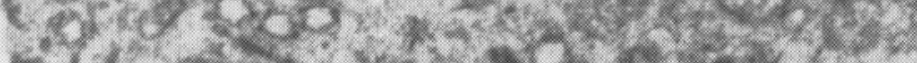

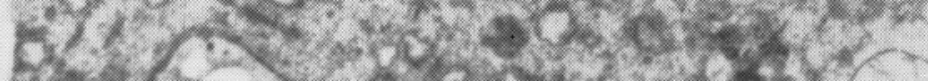

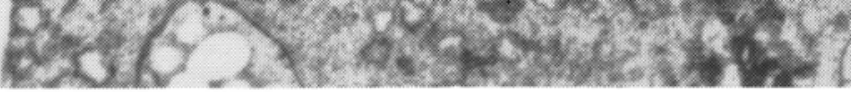

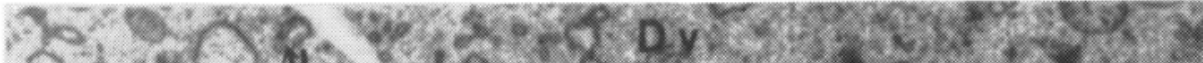

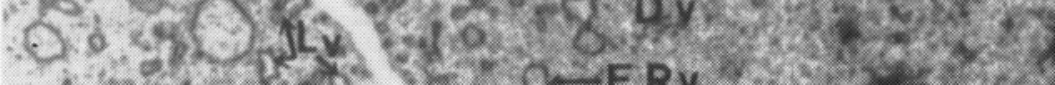

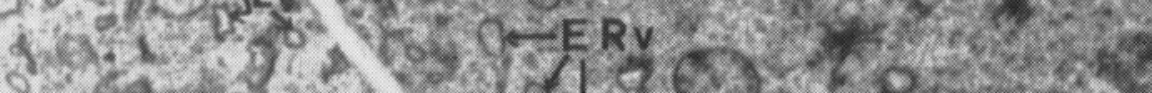

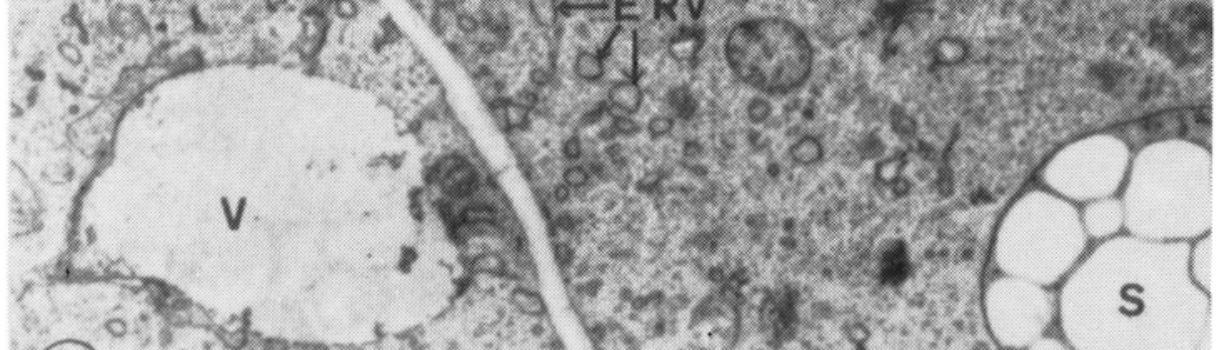

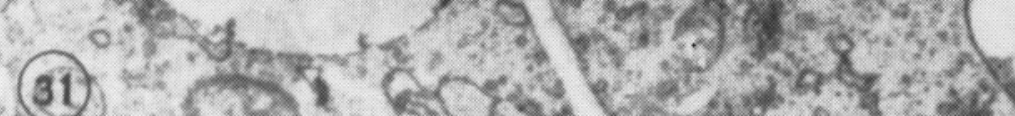

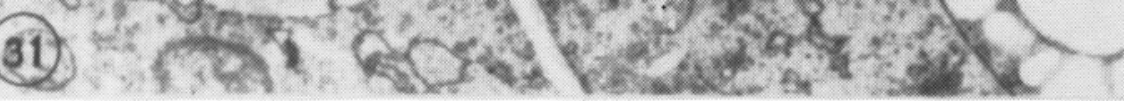

Cw

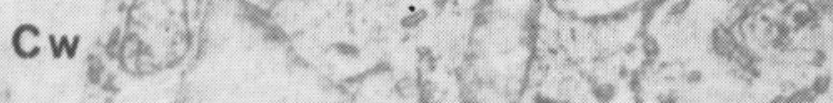

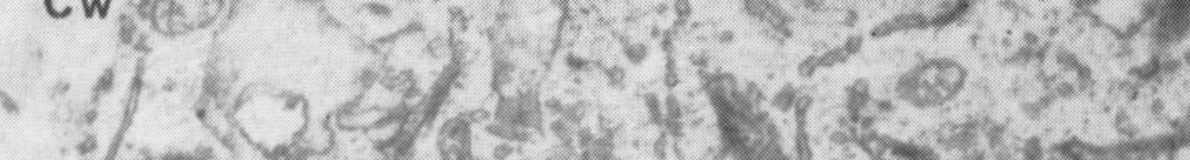

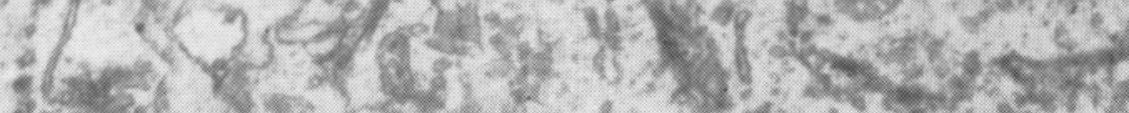

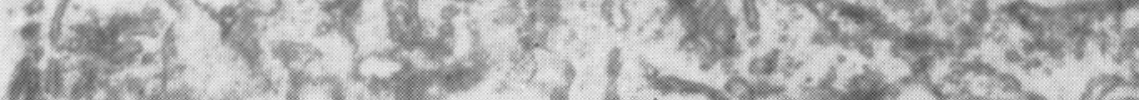

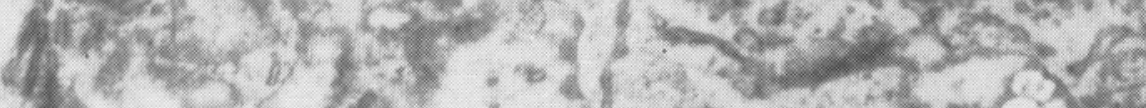

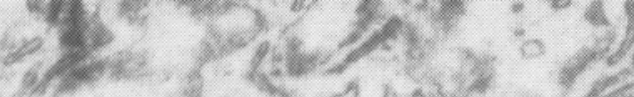

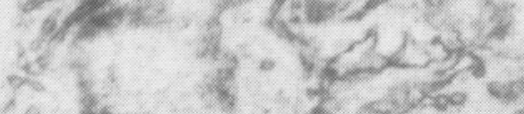

2. $\mathrm{Pb}$

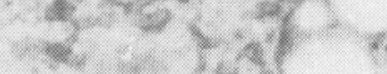

क.

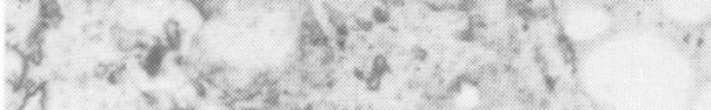

PI

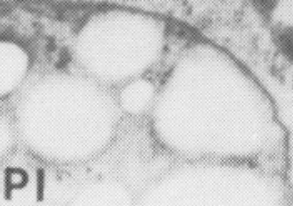

\section{S}




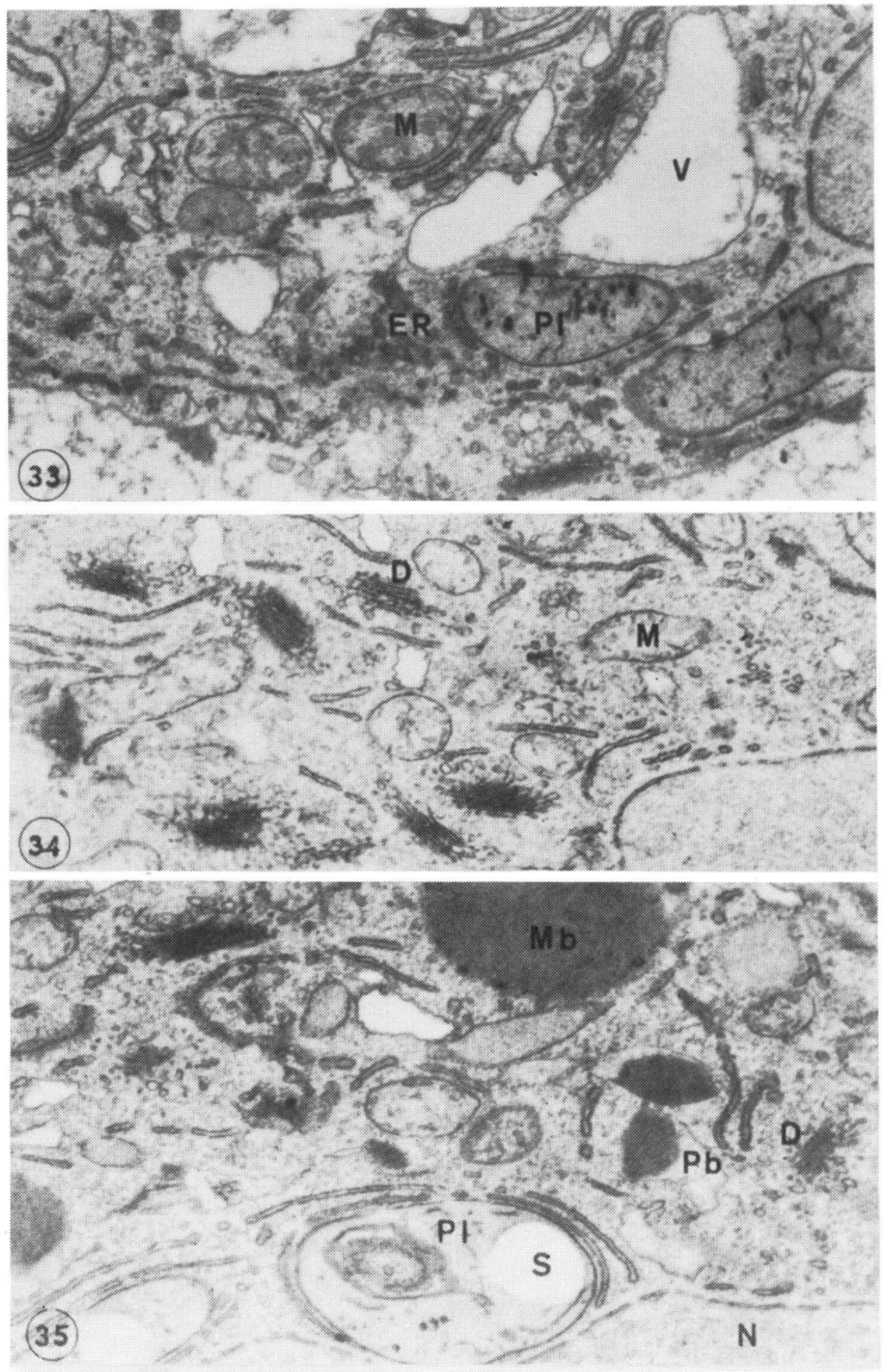


PLATE VII

Figs. 24-26. Columella after germination (1-mm roots). Fig. 24 - Promeristem. Few ER cisternae, some bound with nuclear envelope. Plastids more starch than before, less lipid bodies. $\times 14000$. Fig. 25 - Layers III and IV. Accumulation of tubular ER (second wave of its formation in these cells). $\times 16000$. Fig. $26-$ Layer I. Joining of ER tubules into cisternae. $\times 14000$. Abbreviations as on Plate I

PLATE VIII

Figs. 27-29. Hypocotyl-root boundary after germination (1-mm roots). Fig. 27 - Layer I of root-cap. Plastids (with starch grains), numerous mitochondria, dictyosomes and hydrolysing protein bodies. $\times 20000$. Fig. $28-$ Dermatogen. Ultrastructure similar as in Fig. 27, There are some larger lipid bodies (L). $\times 20000$. Fig. 29 -Cortex layer II. Ultrastructure less differentiated than in Figs. 27 and 28. Vesicular ER, mitochondria at cell wall. $\times 18000$.

Dv - dictyosomal vesicles. Other abbreviations as on Plate I

PLATE IX

Figs. 30-32. Columella of 5-mm roots. Fig. $30-$ Promeristem. Active-looking organelles; few lipids in cell centre, numerous starch grains. $\times 16000$. Fig. $31-$ Central part of columella. Vesicular ER. Vacuolise protein bodies, plastids with starch grains. $\times 16000$. Fig. $32-$ Layer I. Plastids with starch grains, ameboidal protein bodies, partly hydrolysed. $\times 20000$, Lv - lipid vesicles. Other abbreviations as on Plate I

PLATE $X$

Figs. 33-35. Basal, elongating part of 5-mm root. Fig. 33-Layer I of root-cap. Vacuolised cells, large amounts of ER, mitochondria and starchless plastids $\times 20000$. Fig. $34-$ Layer I of root-cap. Dictyosomes. $\times 20000$. Fig. 35 - Dermatogen. Active-looking organelles (like in Fig. 34). Dense inclusions in vacuoles and microbodies $(\mathrm{Mb}) . \times 20000$.

Other abbreviations as on Plate I

cells the ER does not change significantly - few long cisternae lie close to cell walls and nuclei.

Other ultrastructural modifications also shift in basal direction and occur in columella layers IV and V. Starch is now present in the whole columella and promeristem. In the zone where starch grains appeared earlier, their number and size increase (Fig 18). So does the number and range of occurrence of active dictyosomes. Lipid vesicles decrease in number and size. Less dense areas appear in the protein bodies of columella layer I (Fig. 20). In the remaining layers protein bodies are not numerous and preserve their homogeneity. Similar protein bodies lie at the hypocotyl-root boundary, although this zone exhibits a further degree of ultrastructural differentiation. Dictyosomes and dictyosomal vesicles, plastids with starch and elongated mitochondria rich in cristae increase in number 
(Figs. 21-23). The zone with organelles of such an active appearance increases in all directions. ER, however, undergoes almost complete degradation. In the external layers of the hypocotyl-root boundary there is hardly any ER (Figs. 21 and 22). In cells placed further from this zone there still are some cisternae and vesicles (Fig. 23).

ULTRASTRUCTURE OF CELLS IMMEDIATELY AFTER GERMINATION

Columellae of various $1-\mathrm{mm}$ roots differ in ultrastructure. In some columellae a very large number of short ER tubules, so far unseen, accumulate along the walls, especially large in layers II-IV (Fig. 25). Vesicular elements prevail in layer V. In the promeristem a small number of short narrow ER cisternae continue to exist in (Fig. 24). These cisternae are now frequently connected with the nuclear envelope. In some roots the ER is less abundant; in the columella layer I it has the form of long tubules (Fig. 26), while it is vesicular in the remaining layers.

Numerous plastids are present within the columella and promeristem. The columella contains more starch than before. Particularly large grains occur in layers II and III, where plastids are often situated in an apical part and the nucleus in a basal part of the cell. The mitochondria are very long, rich in cristae and frequently constricted. The zone with dictyosomes and dictyosomal vesicles increases and comprises the promeristem (Fig. 24). The lipid vesicles disappear almost completely in the parietal zone, although a few remain dispersed in the cytoplasm. Degradation of protein bodies progresses in layer I.

There is a further change of ultrastructure in cells at the hypocotyl-root boundary. This zone elongates intensively and accumulates very high number of organelles, especially there is reappearance of ER (Figs. 27-29) and marked increase of the number of very active dictyosomes. The greatest number of ER types occurs in the root-cap layer I and in dermatogen (Figs. 27 and 28) just under the hypocotyl border. Numerous long cisternae form layers at the walls; short tubules and vesicles seem to be joining into chains. In the dermatogen and subdermatogen vesicular ER prevail, but plastids are surrounded by shorter and longer cisternae (Fig. 28). In the cortex and parts of the subdermatogen further from the hypocotyl border there were only ER vesicles (Fig. 29).

Other organelles are variously shaped in the particular areas at the hypocotyl-root boundary. Largest plastids of an irregular shape are most numerous in the external layers (Fig. 27). In these plastids the number of thylakoids increases and that of plastoglobules decreases. In the dermatogen and cortex the amount of starch is greatly increased; only in the layer I of the root-cap the starch grains continue to be scarce and very small. 
Mitochondria of various shapes and sizes are more numerous in surface layers of the border zone than in layers placed deeper in the cortex where smaller spherical mitochondria prevail with a greatly reduced number of cristae (cf. Figs. 27 and 29).

The protein bodies are changed. They are looser and in their homogeneous ground substances numerous small electron-clear spaces appear. The beginning of protein bodies degradation becomes most pronounced in layer I of the root-cap and close to its upper border in the dermatogen (Figs. 27 and 28). The lipid vesicles are gradually translocated to the interior of cells of dermatogen and external cortex layers at the hypocotyl-root boundary, whereas in the deeper layers they are still agglomerated close to the walls (cf. Figs. 28 and 29).

The columella layer I differs in ultrastructure from the remaining ones. It has an active appearance, owing to the large number of long cisternae or strands of short ER elements, some of which are frequently parallel to the walls (Fig. 32). Also, there is a large amount of active dictysomes and dictyosomal vesicles. Randomly distributed plastids contain numerous spherical starch grains, much smaller than those in the remaining columella layers. The cell nucleus continues to be folded. Few lipid vesicles are dispersed throughout the cell. The protein bodies transform into irregulary shaped vacuoles with dense inclusions at the edges (Fig. 32).

In the remaining columella layers ER is much less abundant. It has the form of short cisternae or vesicles of various diameters, some larger vesicles contain rather dense materials. Also, there are numerous smaller dictyosomal vesicles and few reduced lipid vesicles. Plastids are filled with polyhedral starch grains (Fig. 31). Vacuolised and greatly elongated columella cells contain plastids with large starch grains nearly always at the apical pole and the nucleus at the basal pole. Protein bodies are transformed into optically empty vacuoles containing only few fibrous precipitates (Fig. 31). In the promeristem ER cisternae, tubules and vesicles are dense, mitochondria rich in cristae and plastids filled with starch (Fig. 30).

At the hypocotyl-root boundary the ultrastructure is modified in a greater number of cells than before, there are more ER and dictyosomes (Figs. 33-35). Particularly abundant ER occurs in layer $I$ of the root-cap at the hypocotyl border. ER cisternae plates of various length, are mainly situated. along cell walls and near organelles (Fig. 33). Dermatogen and all the cortex layers also contain much more ER than previously (Figs. 34 and 35). In the whole dermatogen long ER cisternae lie often around plastids and nucleus (Fig. 35). Similar distribution displays ER in a large part of the dermatogen of the hypocotyl which is then greatly elongated. 
In dermatogen and subdermatogen the ER proliferation zone has only slightly shifted in acropetal direction. Below this zone ER is less abundant, mainly as short, often constricted, tubules and vesicles. ER distribution in the cortex is similar. Elongated elements prevail at the hypocotyl-root boundary and somewhat above it. Below this boundary and also much higher in the hypocotyl there is much less ER and the tubules are short. In comparison with the preceding period, the zone of maximal accumulation of elongated ER elements is distinctly shifted upwards. The profusion of ER in elongating cells may indicate that it is related to the phase of elongation and differentiation of meristematic cells. At the hypocotyl-root boundary mitochondria and plastids are very numerous. Specially large constricted mitochondria with many cristae and constrictions are present in the root-cap layer I (Fig. 33). Plastids are large and elongated with numerous short thylakoids and plastoglobules, sometimes with small starch grains. In the root-cap layer I active dictyosomes are very numerous and many dictyosomal vesicles accumulate in the parietal cytoplasm (Fig. 34), where numerous electron dense spherical bodies occur. This is connected with the considerable thickening of the walls.

Dermatogen, cortex and root-cap layer I contain numerous organelles. Cells of the deeper cap layers have large plastids often with starch grains (Fig. 35). The dermatogen cells, especially those above the hypocotyl border, contain many dictyosomes (Fig. 34). Characteristic for this stage in dermatogen and cortex is the appearance of variously-shaped homogeneous dense bodies within protein vacuoles (Fig. 35). They are abundant smaller and irregular in the external layers, whereas in the deeper layers they are much larger and usually spherical. Equally dense, but always spherical bodies, containing dark inclusions, occur in cells of dermatogen and cortex at the hypocotyl-root boundary (Fig. 35).

\section{DISCUSSION}

Very regular anatomical, cytological and cytochemical changes occur in embryos of germinating rape seeds (Kuraś 1978, 1986). They start in two strictly defined zones: the root-cap columella and the hypocotyl-root boundary; from there they spread wave-like to the whole embryo. Thus, the question arose how this regular course of activation is related to the ultrastructure. The cell structure of dry resting rape embryo is greatly reduced, but the degree of this reduction is not equal in various parts of the embryo (Kuraś 1986). Differentiated cell ultrastructure of resting 
embryos has been described in other plants (Öpik 1966, Bagley et al. 1963, Paulson and Srivastava 1968, Swift and O'Brien 1972, Mia and Durzan 1977, Dawidowicz-Grzegorzewska and Lewak 1978). In the resting rape embryo two kinds of cells can be distinguished: storage cells (mainly in the cotyledons and hypocotyl) are full of protein and lipid bodies with sqeezed in between cytoplasm and few greatly reduced organelles. Meristematic cells (mainly in root and shoot apices) such cells at the columella and at hypocotyl-root boundary exhibit the least reduced ultrastructure. They have a rarefied cytoplasm with well preserved ER elements, plastids and mitochondria which still have a highly active appearance. Activation of starch and DNA synthesis growth and cell division in these zones of the embryo start (Kuraś 1986). Within columella cells of apical layers look more active than those at basal layers. At the hypocotyl-root boundary dermatogen cells seem to have the least reduced ultrastructure. The ultrastructure becomes gradually reduced in the deeper cortex layers and in both directions along the embryo axis. The structural manifestation of cell activation becomes noticeable first in cells preserving the least regressed ultrastructure, and later in those with a more reduced ultrastructure. Accurate follow-up of the sequence of these changes requires limitation of studies to a small group of cells identifiable during germination. This is possible in rape embryo owing to its regular anatomical structure (Kuras 1978).

The ultrastructure of organelles preexisting in the resting embryo develops during germination. Some organelles seem to be formed de novo and the protein and lipid bodies undergo degredation. This has been described in extensive material: Nieuwdorp and Buys (1964), Öpik (1966), Bain and Mercer (1966), Srivastava and Paulson (1968), Briarty et al. (1970), Hallam et al. (1972), Horner and Arnott (1966), Klein and Ben-Shaul (1966), Webster and Leopold (1977), Morrison et al. (1979), Sargent and Osborne (1980) and others. It is, however, difficult to ascertain how the ultrastructural changes begin and in what sequence they occur. Yoo (1970) affirms that the first symptoms of metabolic activity in the fine structure appear in organelles of the resting embryo. Hallam et al. (1972), Swift and O'Brien (1972), Webster and Leopold (1977), Morrison et al. (1979), Jelsema et al. (1980) and Sargent and Osborne (1980) believe that activation is manifested by formation of new membraneous structures (ER and dictyosomes). Others, for instance, Bain and Mercer (1966) consider that the first modifications of the ultrastructure involve storage materials, and attribute the formation of membraneous structures, to imbibition and partial degradation of lipid bodies. This degradation precedes genesis of the first ER structures.

From our investigations of the germinating rape seed it appears that in the fine structure the first symptom of activation is the appearance 
of the ER. It was well visible owing to postfixation in $\mathrm{KMnO}_{4}(\mathrm{Mol}$ lenhauer and Totten 1971, Kuraś 1984). ER vesicles become visible in columella after $3 \mathrm{~h}$ of soaking or even after $1 \mathrm{~h}$ (Auguścik and Kuraś - unpublished). Their further morphological transformations allow to distinguish clearly the ER development phases, similar to these distinguished by Öpik (1966), Bain and Mercer (1966), Klein and Ben-Shaul (1966), Jones (1969a, b), Briarty et al. (1970). Villiers (1971), Jelsema et al. (1980), Gilkes and Chrispeels (1980), Bergfeld and Schopfer (1984).

The first phase - up to 6 h of seed swelling - there is mass appearance of ER and its transformation. The second phase $(6-14 \mathrm{~h})$ ER disintegrates and disappears almost completely. During the third phase (preceding germination) ER reappears rapidly in large amounts. After germination the ultrastructure stabilises, the amount of ER greatly diminishes, but part of it, mainly as large vesicles (in the columella) or diverse cisternae (in the elongation zone) remain during development of the root apical meristem.

Particularly interesting is the first phase of ER formation comprising the beginning of imbibition. The presence of ER in this period has been ascertained by many authors (Bain and Mercer 1966, Klein and Ben-Shaul 1966, Srivastava and Paulson 1968, Jones 1969a, b, Briarty et al. 1970, Webster and Leopold 1977, Sargent and Osborne 1980, Bergfeld and Schopfer 1984). It results from the present studies and those by Hallam et al. (1972), Webster and Leopold (1977), Chrispeels and Jones (1980) and Jelsema et al. (1980), that in this phase ER is not formed the nuclear envelope. It may be assumed therefore that ER is formed de novo or from elements preexisting in the resting embryo. Solution of this problem requires further studies. It may be concluded from the presented observations and unpublished data obtained with the use of protein synthesis inhibitors that ER seems to arise from preexisting elements. ER appears suddenly in a very large amount and in different forms soon after seed imbibition. Such so sudden de novo production of ER seems unlikly. On the other hand, assumption as ER assembly from preexisting elements is supported by Bergfeld and Schopfer (1984) and also, to some degree, by the fine structure of columella of the rape radicle in the final phase of ripening seed when ER has the same form and localisation as in the initial phase of imbibition (Kuraś et al. 1986, Tykarska and Kuraś - unpublished).

The role of ER at the beginning of the swelling phase is not clear. It is supposed that it may transport and store nutrients, mainly saccharides (Bain and Mercer 1966, Webster and Leopold 1977). It is, also probable that the tubular ER arising in such profusion is the site of synthesis and transport of hydrolytic enzymes and/or growth substances 
triggering metabolic processes and making germination possible (Bain and Mercer 1966, Öpik 1966, Jones 1969a, b, Chrispeels and Boutler 1975, Webster and Leopold 1977, Chrispeels and Jones 1980, Harris and Chrispeels 1980, Bergfeld and Schopfer 1984). Formation of these substances in the initial period of activation, may be based on preexisting enzymes; therefore, it is not under actual genetic control of the nucleus which is activated later. The second wave of protein and RNA synthesis, would, on the other hand, be the effect of an activation of the genetic apparatus; perforation of the seed coat and appearance of radicles would be its effect.

Development of the ER is directly followed by that of dictyosomes. There are no typical dictyosomes in resting seed embryos (ref. Kuraś 1984). In the root columella and dermatogen at the hypocotyl-root boundary of resting rape embryos agglomerations of small vesicles are found. The dimensions of these vesicles and the shapes of their agglomerations, may suggest that they arose after dictyosome fragmentation (Kuraś 1984). Also, in the coleorhiza of resting rye seeds Sargent and Osborne (1980) observed compact concentric profiles of intensively staining membranes which may represent a condensed form of dictyosomes. The first dictyosomes appear after different time periods in embryos of various species: after $1 \mathrm{~h}$ in the rye coleorhiza (Sargent and Osborne 1980), after $3 \mathrm{~h}$ in rye root (Hallam et al. 1972) and in the wheat scutellum (Swift and O'Brien 1972), after $24 \mathrm{~h}$ in the axis of the lettuce embryo (Srivastava and Paulson 1968), and in pea cotyledons (Bain and Mercer 1966), still later, after 2-8 days in Vicia faba cotyledons (Briarty et al. 1970). This review indicates that, independently of differences between species, dictyosomes appear earlier in the radicle and embryo axis than in the cotyledons. The gradual spread of dictyosomes and their activation are described among others by Srivastava and Paulson (1968) and Sargent and Osborne (1980). The present investigations show that there are large differences in the time of appearance of dictyosomes, within the embryo, and even within the radicle. The first few, not very active dictyosomes appeared after $6 \mathrm{~h}$ of imbibition in the apical part of the columella (layers I and II). In layer III dictyosomes appeared sporadically and were absent in the remaining part of the embryo axis. In the columella the number, size and range of occurrence of active dictyosomes increased distinctly from 6 th to 14 th hour, and in the external parts of the hypocotyl-radicle boundary - after $14 \mathrm{~h}$. In the $1-\mathrm{mm}$ roots of germinating seeds the zone of dictyosomes-containing cells is extended to the whole promeristem and the lateral parts of the root-cap. At the same time, the number and range of active dictyosomes increased in the basal part of the root. Particularly large number of active dictyosomes and dictyosomal visicles were present in the basal zone of the 5-mm root. 
Numerous dictyosomal vesicles accumulated along the walls of the first cap layer probably are connected with thickening of the walls.

Like in the case of ER, it is important to know how dictyosomes arise. It seems that the regressed dictyosomes in the resting embryo (found among others by Sargent and Osborne 1980, and Kuraś 1984) may be reconstructed as the result of hydration. According to Swift and O'Brien (1972) $3 \mathrm{~h}$ interval seem too short for the de novo formation of dictyosome membrane units, and during soaking these membranes probably are self-assembled from the pre-existing subunits. Thus, it is highly probable that at least the earliest arising dictyosomes (like the first ER), are derived from preexisting units, and only the later ones result from de novo biosynthesis.

The distinctly wave-like course of activation in germinating embryos is manifested in the development of membraneous structures, and ultrastructure of the nucleus, plastids and mitochondria, which preserved their morphological distinctiveness throughout the whole resting period of the seed. The gradual course of activation of germinating seed is particularly noticeable in course of protein bodies degradation. In the resting embryo they are very numerous, of rather homogenous structure. They differ widely in size, shape and amount in various parts of the embryo and constitute an important factor of cell differentiation in the resting embryo. This differentiation determines to a large extent, the pattern of activation processes in germinating embryo. The large amount of protein bodies gives the cells features of storage tissue in which some organelles undergo maximal regression (Kuraś 1984). Less modified organelles are preserved in cells containing less protein bodies. Such cells are in a state of greater metabolic readiness and start their activity when the indispensable physical conditions are available. The presence of protein bodies and differentiation of their form determine, thus, the time of activation. In germinating rape embryos degradation of protein bodies begins first in the radicle, then in the hypocotyl and finally in the cotyledons, i.e. exactly in the same order as in germinating lettuce (Srivastava and Paulson 1968) and stratified apple seeds (Dawidowicz-Grzegorzewska and Żarska-Maciejewska 1979). The process of degradation of protein bodies gradually involves the consecutive organs. In the rape root this process (like processes described in the present and preceding paper-Kuraś 1986) starts in the columella and hypocotyl-radicle boundary, and then spreads throughout the embryo. The time of degradation of protein bodies in Yucca embryos also is dependent on the tissue (Horner and Arnott 1966). These bodies first disappear in the procambium - after two days, and after four days - in the protoderm and basal parenchyma. Such a sequence of activation may result from the axis impulse flow to cotyledons, as found, among others by Wiley and Ashton (1967) and Hoffmannowa (1978). 
It seems, however, that the gradual spread of protein body mobilization within the organs is the consequence of histological differentiation.

The structurally determined course of activation may change under modified conditions, like in isolated apple embryos activated without stratification (Dawidowicz-Grzegorzewska 1981).

The causes of such a regular course of activation are not known. Undoubtedly, the regular patterns of ultrastructural changes, and reserve mobilization are precisely determined. It is also unquestionable that the spatial order of the ultrastructural changes in the germinating embryo precedes the wave-like course of the anatomical and cytological manifestations of metabolic activation. It may, thus, be assumed that the wave-like course of embryo activation is related to the wave-like course of alterations in the fine structure.

\section{Acknowledgements}

The author thanks Professor R. Willey (Univ. Ill. at Chicago Circle) for making possible the performance of part of these experiments and very cordial helpful; Professor H. Teleżyński and Professor B. Rodkiewicz for their helpful discussions; to J. Auguścik, M. Sc., for technical assistance.

\section{REFERENCES}

Bagley B. W., Cherry J. H., Rollins M. L., Altschul A. M., 1963. A study of protein bodies during germination of peanut (Arachis hypogea) seed. Amer. J. Bot. 50: 523-532.

Bain J. M., Mercer F. V., 1966. Subcellular organization of the cotyledons in germinating seeds and seedlings of Pisum sativum L. Aust. J. Biol. Sci. 19: 69-84.

Bergfeld R., Schopfer P., 1984. Transistory development of rough endoplasmic reticulum aggregates during embryo maturation in seeds of mustard (Sinapis alba L.). Europ. J. Cell. Biol. 34: 27-33.

Briarty L. G., Coult D. A., Boulter D., 1970. Protein bodies of germinating seeds of Vicia faba. J. Exp. Bot. 21: 513-524.

Chrispeels M. J., Boulter D., 1975. Control of storage protein metabolism in cotyledons of germinating mung beans: role of endopeptidase. Plant Physiol. 55: 1031-1037.

Chrispeels M., Jones R. L., 1980. The role of the endoplasmic reticulum in the mobilization of reserve macromolecules during seedling growth. Israel J. Bot. 29: 225-245.

Dawidowicz-Grzegorzewska A., 1981. Anatomy, histochemistry and cytology of dormant and stratified apple embryos. III. Structural changes during the early development of seedlings in relation to embryo dormancy. New Phytol. 87: 573-579.

Dawidowicz-Grzegorzewska A., Lewak St., 1978. Anatomy, histochemistry and cytology of dormant and stratified apple embryos. New Phytol. 81: 99-103.

Dawidowicz-Grzegorzewska A., Żarska-Maciejewska B., 1979. Anatomy, histochemistry and cytology of dormant and stratified apple embryos. III. Storage protein degradation and corelated nucleoli development. New Phytol. 83: 385-393.

Gilkes N. R., Chrispeels M. J., 1980. The endoplasmic reticulum of mung-bean cotyledons. Planta 149: 361-369. 
Hallam N. D., Roberts B. E., Osborne D. J., 1972. Embryogenesis and germination in rye. .II. Biochemical and fine structural changes during germination. Planta 105: 293-309.

Harris N., Chrispeels M. J., 1980. The endoplasmic reticulum of mung-beam cotyledons: quantitative morphology of cisternal and tubular ER during seedling growth. Planta 148: 293-303

Hoffmannowa A., 1978. Control of starch mobilization in cotyledons of germinating yellow lupin (Lupinus luteus L.). Biochem. Physiol. Pflanz 173: 181-185.

Horner H. T., Arnott H. J., 1966. A histochemical and ultrastructural study of pre and post-germinated Yucca seeds. Bot. Gaz. 127: 48-64.

Jelsema C. L., Powell M. J., Morre D. J., Ruddat M., Mollenhauer H. H., 1980. Isolation of lamellar bodies from aleurone layers of wheat grains. Bot. Gaz 141: 139-148.

Jones R. L., 1969a. Gibberellic acid and the fine structure of barley aleurone cells. Planta (Berl.) 87: 119-133.

Jones R. L., 1969b. Gibberellic acid and the fine structure of barley aleurone cells. II. Changes during the synthesis and secretion of $\alpha$-amylase. Planta (Berl.) 88: 73-86.

Klein S., Ben-Shaul Y., 1966. Changes in cell fine structure of lina bean axes during early germination. Can. J. Bot. 44: 331-340.

Kuraś M., 1978. Activation of embryo during rape (Brassica napus L.) seed germination. I. Structure of embryo and organization of root apical meristem. Acta Soc. Bot. Pol. 47: $65-82$.

Kuraś M., 1984. Activation of embryo during rape (Brassica napus L.) seed germination. III. Ultrastructure of dry embryo axis. Acta Soc. Bot. Pol. 53: 171-186.

Kuraś M., 1986. Activation of embryo during rape (Brassica napus L.) seed germination. IV. Germinating embryo. The first zones of mitoses, starch and DNA synthesis and their expansion pattern. Acta Soc. Bot. Pol. 55: 539-563.

Kuraś M., Tykarska T., Auguścik J., 1986. Ultrastructural changes in the columella cells of rape (Brassica napus L.) during seed maturation and germination. Folia Histochem. Cytochem. (in press).

Mia A. J., Durzan D. J., 1977. Cytochemical and subcellular organization of root apical meristems of dry and germinating jack pine embryos. Can. J. Forest Res. 7: 263-276.

Mollenhauer H. H., Totten C., 1971. Studies on seeds. I. Fixation of seeds. J. Cell. Biol. 48: 387-394.

Morrison Baird L. A., Leopold A. C., Bramlage W. J., Webster B. D., 1979. Ultrastructural modifications associated with imbibing of the soybean radicle. Bot. Gaz. 140: 371-377.

Nieuwdorp P. J., Buys M. C., 1964. Electron microscopic structure of the epithelial cells of the scutellum of barley. II. Cytology of the cells during germination. Acta Bot. Neerl. 13: 559-565.

Öpik H., 1966. Changes in cell fine structure in the cotyledons of Phaseolus vulgaris L. during germination. J. Exp. Bot. 17: 427-439.

Paulson R. E., Srivastava L. M., 1968. The fine structure of the embryo of Lactuca sativa. I. Dry embryo. Can. J. Bot. 46: 1437-1445.

Reynolds E. S., 1963. The use of lead citrate at high $\mathrm{pH}$ as an electron-opaque stain in electron microscopy. J. Cell. Biol. 17: 208-213.

Sargent J. A., Osborne D., 1980. A comparative study of the fine structure of coleorhiza and root cell during the early hours of germination of rye embryos. Protoplasma 104: 91-103.

Srivastava L. M., Paulson R. E., 1968. The fine structure of the embryo of Lactuca sativa. II. Changes during germination. Can. J. Bot. 46: 1447-1453. 
Swift J. G., O'Brien T. P., 1972. The fine structure of the wheat scutellum during germination. Aust. J. Biol. Sci. 25: 469-485.

Villiers T. A., 1971. Cytological studies in dormancy. I. Embryo maturation during dormancy in Fraxinus excelsior. New Phytol. 70: 751-760.

Webster B. D., Leopold A. C., 1977. The ultrastructure of dry and imbibed cotyledons of soybean. Amer. J. Bot. 64: 1286-1293.

Wiley L., Ashton F. M., 1967. Influence of the embryonic axis on protein hydrolysis in cotyledons of Cucurbita maxima. Physiol. Plant. 20: 688-696.

Ioo B. Y., 1970. Ultrastructural changes in cells of pea embryo radicles during germination. J. Cell Biol. 45: 158-171.

Aktywacja zarodka podczas kielkowania nasion rzepaku (Brassica napus L.). V. Strefy pierwszych zmian ultrastruktury oraz ich rozprzestrzenianie sie

\section{Streszczenie}

W kiełkującym zarodku rzepaku najwcześniej ulegają aktywacji komórki kolumelli i bazalnej części hypokotyla. Pierwszym ultrastrukturalnym przejawem aktywacji jest pojawienie się po 3-6 godz. pęcznienia dużej liczby pęcherzyków ER. W kolumelli największa liczba pęcherzyków jest w komórkach warstw zewnętrznych i zmniejsza się w kierunku bazypetalnym. W bazalnej strefie hypokotyla komórki dermatogenu mają najwięcej struktur ER i ilość ich zmniejsza się w obu kierunkach wzdłuż osi zarodka oraz centrypetalnie. W takim samym porządku rozprzestrzeniają się dalsze zmiany ER. Pęcherzyki zlewają się tworząc ER tubularne i płatowate. W następnej fazie, ER całkowicie zanika po czym ponownie pojawiają się formy tabularne, pęcherzykowate i długie cysterny ER. W ślad za zmianami ER stopniowo rozprzestrzeniają się ultrastrukturalne przejawy aktywacji mitochondriów, plastydów i diktiosomów. Najwięcej struktur ER i pozostałych organelli nagromadza się w komórkach korzenia bezpośrednio przed przebijaniem łupiny nasiennej. Po wykiełkowaniu ilość ich zmniejsza się i utrzymuje się na prawie jednakowym poziomie. 